\title{
Cloning and Expression of the Succinyl-CoA Synthetase Genes of Escherichia coli K12
}

\author{
By DAVID BUCK, MARGARET E. SPENCER AND JOHN R. GUEST* \\ Department of Microbiology, University of Sheffield, Sheffield S10 2TN, UK
}

(Received 14 October 1985; revised 21 January 1986)

\begin{abstract}
The genes encoding both subunits of the succinyl-CoA synthetase of Escherichia coli have been identified as distal genes of the suc operon, which also encodes the dehydrogenase (E1o; sucA) and succinyltransferase $(\mathrm{E} 2 \mathrm{o} ; s u c B)$ components of the 2-oxoglutarate dehydrogenase complex. The newly defined genes express polypeptides of $41 \mathrm{kDa}(\operatorname{sucC})$ and $31 \mathrm{kDa}(\operatorname{sucD})$, corresponding to the $\beta$ and $\alpha$ subunits of succinyl-CoA synthetase, respectively. The genes are thus located at $16.8 \mathrm{~min}$ in the $E$. coli linkage map, together with the citrate synthase $(\mathrm{glt} A)$ and succinate dehydrogenase $(s d h)$ genes, in a cluster of nine citric acid cycle genes: $\stackrel{\leftrightarrow}{g t} \mathbf{A}-\overrightarrow{s d h C D A B}$ $\overrightarrow{s u C A B C D}$. Four deletion strains lacking all of these citric acid cycle enzymes were characterized. The succinyl-CoA synthetase activities of strains harbouring plasmids containing the sucC and $s u c D$ genes were amplified some fourfold. Further enzymological studies indicated that expression of succinyl-CoA synthetase is coordinately regulated with 2-oxoglutarate dehydrogenase.
\end{abstract}

\section{INTRODUCTION}

The succinyl-CoA synthetase (SCS; EC 6.2.1.5) of Escherichia coli catalyses the reversible thioesterification of succinate:

$$
\text { Succinate }+\mathrm{CoA}+\mathrm{ATP} \stackrel{\mathrm{Mg}^{2+}}{\rightleftharpoons} \text { Succinyl-CoA }+\mathrm{ADP}+\mathrm{P}_{\mathrm{i}}
$$

It plays an essential role in the citric acid cycle, where the conversion of succinyl-CoA to succinate represents an important site of substrate level phosphorylation. It also functions to generate succinyl-CoA from succinate for anabolic purposes when the route from 2-oxoglutarate is repressed, e.g. under anaerobic conditions. The $E$. coli enzyme $\left(M_{\mathrm{r}} 136000\right)$ contains two types of polypeptide chain, the $\alpha\left(M_{\mathrm{r}} 29500\right)$ and $\beta\left(M_{\mathrm{r}} 38500\right)$ subunits, which are assembled as $(\alpha \beta)_{2}$ tetramers (Bridger, 1974; Vogel \& Bridger, 1982). This contrasts with the succinyl-CoA synthetases of eukaryotes and Gram-positive bacteria, which are smaller $\left(M_{\mathrm{r}}\right.$ approx. 70000), and exist as $\alpha \beta$ dimers : the enzymes from different sources differ in their preferences for adenine and guanine nucleotides (Weitzman, 1981).

No mutants lacking succinyl-CoA synthetase have been characterized, but there is indirect evidence to suggest that SCS may be expressed from the $16.8 \mathrm{~min}$ region of the linkage map, which contains a cluster of citric acid cycle genes (Bachmann, 1983). This cluster includes the citrate synthase gene ( $g l t A)$, the succinate dehydrogenase operon ( $s d h C D A B)$, and an operon (sucAB) encoding the dehydrogenase (Elo; sucA), and succinyltransferase (E2o; sucB) components of the 2-oxoglutarate dehydrogenase complex (Wood et al., 1984; Darlison \& Guest, 1984; Darlison et al., 1984; Spencer et al., 1984). Transcription of the glt A and sdh genes diverges from a common intergenic region, and the $s u c$ genes are flanked by several tandemly-repeated palindromic units or REPs, as follows: $\overleftrightarrow{\text { glt } A}-\overrightarrow{s d h C D A B-(\mathrm{REP})_{3}}-\overrightarrow{s u c A B-(\mathrm{REP})_{4}}$. First, it was observed that SCS activity is reduced in $\operatorname{sucA}$ polar mutants, suggesting that SCS may be expressed from distal genes in the suc operon (Creaghan \& Guest, 1972). Sequence analysis downstream from sucB later revealed several palindrornic units or REPs (once thought to 
function as transcriptional attenuators; Higgins et al., 1982), and also the start of a new coding region (Spencer et al., 1984). More recently two suc transcripts have been detected, one terminating immediately downstream of the $s u c B$ REPs, and the other extending into the new coding region, sucC (Spencer \& Guest, 1985). This strongly indicates that the suc operon contains one or more distal genes, the most plausible candidates being those encoding the $\alpha$ and $\beta$ subunits of SCS.

These findings prompted a detailed study of the distal region of the suc operon, which has led to the discovery of two new genes, encoding the $\beta$ subunit (sucC) and the $\alpha$ subunit (sucD) of succinyl-CoA synthetase. The genes were located in a segment of cloned DNA, and their products were identified by size and enzyme activity. The synthesis of SCS under different growth conditions was investigated enzymologically.

\section{METHODS}

Bacterial strains. The strains of E. coli K12 used are listed in Table 1. Strains ED8641 and GM242 were used routinely as transformation hosts, and $\mathrm{AB} 2480$ served as the maxicell strain. Two recombination-deficient suc mutants, JRG1500 and JRG1501, were constructed for nutritional complementation tests. Five strains with deletions extending from the $k d p$ region to $r d g$ (TK3D27), or from $k d p$ into or beyond gltA (TK3D01, TK3D12, TK3D14 and TK3D18), were kindly provided by W. Epstein for nutritional and enzymological tests: they were originally isolated following aberrant excision of a $\lambda k d p$ prophage (Rhoads $e t$ al., 1978; Froehlich \& Epstein, 1981). Plasmid-containing derivatives of PM191 and the deletion strain TK3D18 were used in the enzymological studies.

Bacteriophages and plasmids. The $\lambda$ gltA sdh sucAB transducing phage, $\lambda$ G118 (Spencer \& Guest, 1982), was used as the source of DNA. Specific restriction fragments were isolated from agarose gels using DEAE-cellulose paper (Dretzen et al., 1981) and subcloned between appropriate sites in the tet gene of pBR322. The relevant plasmids and bacterial inserts are shown in Fig. 1. The methods used for preparing phage and plasmid DNA and the plasmid transformation procedure have been described previously (Stephens et al., 1983).

Media. The complete medium was L broth (Guest, 1981) supplemented with glucose at $1 \mathrm{~g} \mathrm{l}^{-1}(\mathrm{LG}-0 \cdot 1 \%)$ or $10 \mathrm{~g}^{-1}$ (LG-1\%), and the antibiotics ampicillin $\left(100 \mu \mathrm{g} \mathrm{m}^{-1}\right)$ or tetracycline $\left(15 \mu \mathrm{g} \mathrm{ml}^{-1}\right)$ when required. Minimal medium E of Vogel \& Bonner (1956) was used with glucose (11 mM), potassium acetate (50 mM) or sodium 2-oxoglutarate ( $50 \mathrm{mM})$ as substrates, and other supplements to satisfy specific auxotrophic requirements. Media were solidified with Difco Bacto agar at $15 \mathrm{~g} \mathrm{l}^{-1}$.

Maxicell procedure. Polypeptides expressed from plasmid-borne genes were labelled with ${ }^{14} \mathrm{C}$-labelled L-amino acids by the maxicell technique of Sancar et al. (1979). The radioactive polypeptides were analysed fluorographically following SDS-PAGE and treatment with Enlightening (New England Nuclear).

Enzymology. Cultures for enzymology were grown with shaking at $37^{\circ} \mathrm{C}$ in various media $(250 \mathrm{ml})$, starting with overnight cultures in LG- $0.1 \%$ broth $(2.5 \mathrm{ml})$ as inocula. Ampicillin $\left(100 \mu \mathrm{g} \mathrm{ml}^{-1}\right)$ was added to maintain the plasmids, where applicable. Anaerobic cultures were grown in stationary conical flasks $(100 \mathrm{ml})$ filled to the neck with medium. Cultures were harvested in late exponential phase unless stated otherwise, and ultrasonic extracts were prepared and assayed for protein according to Langley \& Guest (1977). The methods for assaying the overall 2-oxoglutarate dehydrogenase complex (ODH complex), 2-oxoglutarate dehydrogenase (E1o; EC 1.2.4.2) and

\section{Table 1. Strains of Escherichia coli K12 used}

\begin{tabular}{|c|c|c|}
\hline Strain & Relevant genotype & Source* and/or reference \\
\hline ED8641 & recA56 supE hsdR & N. E. Murray \\
\hline GM242 & dam-3 recAl supE44 & M. Marinus \\
\hline PM191 & thr-1 leuB6 thi-1 recA & P. Meacock \\
\hline AB2480 & pro-2 thi-1 uvrA6 recA13 & P. J. Emmerson \\
\hline JRG72 & sucAl & Spencer \& Guest (1982) \\
\hline JRG 1500 & sucAl srl:: $\operatorname{Tn} 10 \operatorname{rec} A$ & Tet $^{R} \operatorname{Rec}^{-}$derivative of $\mathrm{JRG} 72$ \\
\hline JRG153 & sucB 17 & Spencer \& Guest (1982) \\
\hline JRG1501 & sucB17 srl ::Tn10 recA & Tet $^{R} \mathrm{Rec}^{-}$derivative of JRG153 \\
\hline TK3D18 & $\Delta(k d p-s u c) \mathrm{D} 18 \Delta(g a l-b i o)$ & W. Epstein \\
\hline TK3D27 & $\Delta(k d p-r d g) \mathrm{D} 27 \Delta(g a l-b i o)$ & W. Epstein \\
\hline
\end{tabular}

* N. E. Murray, Department of Molecular Biology, University of Edinburgh, UK; M. Marinus, Department of Pharmacology, Rutgers Medical School, NJ, USA; P. Meacock, Department of Biochemistry, University of Leicester, UK; P. J. Emmerson, Department of Biochemistry, University of Newcastle, UK; W. Epstein, Department of Biochemistry, University of Chicngo, Ill., USA. 
lipoamide dehydrogenase (E3; EC 1.8.1.4) have been described previously by Langley \& Guest (1977), and for citrate synthase (EC 4.1.3.7) and succinate dehydrogenase (EC 1.3.99.1) by Guest (1981). Dihydrolipoyl succinyltransferase (E2o; EC 2.3.1.61) was assayed at $\mathrm{pH} 7.0$ and $30^{\circ} \mathrm{C}$ by determining the extra thioester formed on adding dihydrolipoamide to a succinyl-CoA generating system, according to Knight \& Gunsalus (1962). An excess of succinyl-CoA synthetase was added to ensure a sufficient supply of succinyl-CoA. SuccinylCoA synthetase (SCS; EC 6.2.1.5) was assayed spectrophotometrically at $230 \mathrm{~nm}$ by the method of Bridger et al. (1969). $\beta$-Lactamase (EC 3 5.2.6) was assayed iodometrically using benzylpenicillin ( $2 \mathrm{mM}$ ) according to Ross \& O'Callaghan (1975). Enzyme specific activities are expressed as $\mu \mathrm{mol}$ substrate transformed (mg protein) ${ }^{-1} \mathrm{~h}^{-1}$ at $25^{\circ} \mathrm{C}$, or at $30^{\circ} \mathrm{C}$ in the case of E2o.

Materials. Restriction enzymes and $\mathrm{T}_{4}$-DNA ligase were obtained from BRL, Boehringer and Gibco-PL, and used according to the manufacturers' instructions. Succinyl-CoA synthetase (pig heart) was obtained from Boehringer and $\left[\mathrm{U}-{ }^{14} \mathrm{C}\right]$ protein hydrolysate from Amersham. Dihydrolipoamide was prepared by reducing lipoamide (Sigma) with sodium borohydride in methanol and water $(4: 1, v / v)$. The product was extracted with chloroform and recrystallized from a benzene/hexane mixture $(2 \cdot 5: 1, \mathrm{v} / \mathrm{v})$.

\section{RESULTS}

\section{Subcloning in the sucAB and downstream region}

The cluster of citric acid cycle genes, which includes citrate synthase $($ glt $A)$, succinate dehydrogenase ( $\operatorname{sdhCDAB}$ ) and the E1o and E2o components of the 2-oxoglutarate dehydrogenase complex (sucA and $s u c B$ ), was isolated previously in a $\lambda$ glt $A$-suc transducing phage ( $\lambda \mathrm{G} 118)$ by the integration and aberrant excision of a $\lambda g l t A$ prophage (Spencer $\&$ Guest, 1982). A map showing the organization and polarities of the seven citric acid cycle genes in the $16.5 \mathrm{~kb}$ segment of bacterial DNA in $\lambda \mathrm{G} 118$ is shown in Fig. 1. The complete nucleotide sequence of a 10903 bp segment containing these seven genes has been established (Ner et al., 1983; Darlison et al., 1984; Spencer et al., 1984; Wood et al., 1984; Darlison \& Guest, 1984). However, the discovery of an open reading frame distal to $s u c B$, together with transcriptional evidence that it could be part of the suc operon (Spencer \& Guest, 1985), prompted an investigation of the unassigned $5.6 \mathrm{~kb}$ downstream region. Several restriction fragments were accordingly subcloned from $\lambda \mathrm{G} 118$ into appropriate sites in the tet gene of pBR322 for detailed mapping and expression studies. The resulting plasmids are illustrated in Fig. 1: pGS64 contains the $5.4 \mathrm{~kb} \mathrm{BamHI-SalI}\left(\mathrm{B}_{3}-\mathrm{S}_{2}\right)$ fragment; pGS128 and pGS129 the $7.0 \mathrm{~kb}$ XhoI-SalI $\left(\mathrm{X}-\mathrm{S}_{2}\right)$ fragment in both orientations; pGS130 the $2.3 \mathrm{~kb} S a l I-B g l I I\left(\mathrm{~S}_{2}-\mathrm{Bg}_{5}\right)$ fragment; and pGS131 and pGS132 the $4.5 \mathrm{~kb} B g I I I-B g l I I\left(B_{4}-\mathrm{Bg}_{5}\right)$ fragment in both orientations. Also shown are two fragments (I and II) which could not be subcloned despite repeated attempts. Starting with a BglII digest of the isolated $\mathrm{S}_{2}-\mathrm{X}_{\lambda}$ fragment and BamHI- plus SalI-cut and phosphatased pBR322, plasmids containing the larger $\mathrm{S}_{2}-\mathrm{Bg}_{5}$ subfragment were easily recovered, but never those containing the smaller $\mathrm{Bg}_{5}-\mathrm{X}_{\lambda}$ subfragment. It is probable that the $\mathrm{Bg}_{5}-\mathrm{X}_{\lambda}$ fragment contains an element which is lethal when overexpressed on a multicopy plasmid. Another plasmid that has also resisted construction is one containing the $\mathrm{X}-\mathrm{Bg}_{5}$ fragment (III in Fig. 1), which should include the entire suc operon with its own promoter (see later).

Plasmids pGS128 and pGS129 were found to complement the $\mathrm{Suc}^{-}$phenotypes of the sucArecA and sucBrecA mutants, JRG1500 and JRG1501, thus confirming the presence of functional suc $A$ and $s u c B$ genes. Plasmid pGS64 complemented the $\operatorname{sucB}$ rec $A$ mutant but not the sucA rec $A$ strain, contrary to an earlier report by Darlison $\epsilon t$ al. (1984) in which a sucA rec ${ }^{+}$strain had been used. Apparently the tet-sucA fusion product lacking the first 181 amino acids of Elo is inactive, but E2o is expressed from the flanking tet promoter. Furthermore, suc deletion strains harbouring pGS64 have no Elo activity (see later). Because there are no mutants of $E$. coli lacking SCS alone, the hypothesis that some of the newly constructed plasmids may contain the SCS genes could not be tested by complementation. Instead the gene products expressed from each plasmid were investigated by the maxicell technique and enzymologically. 


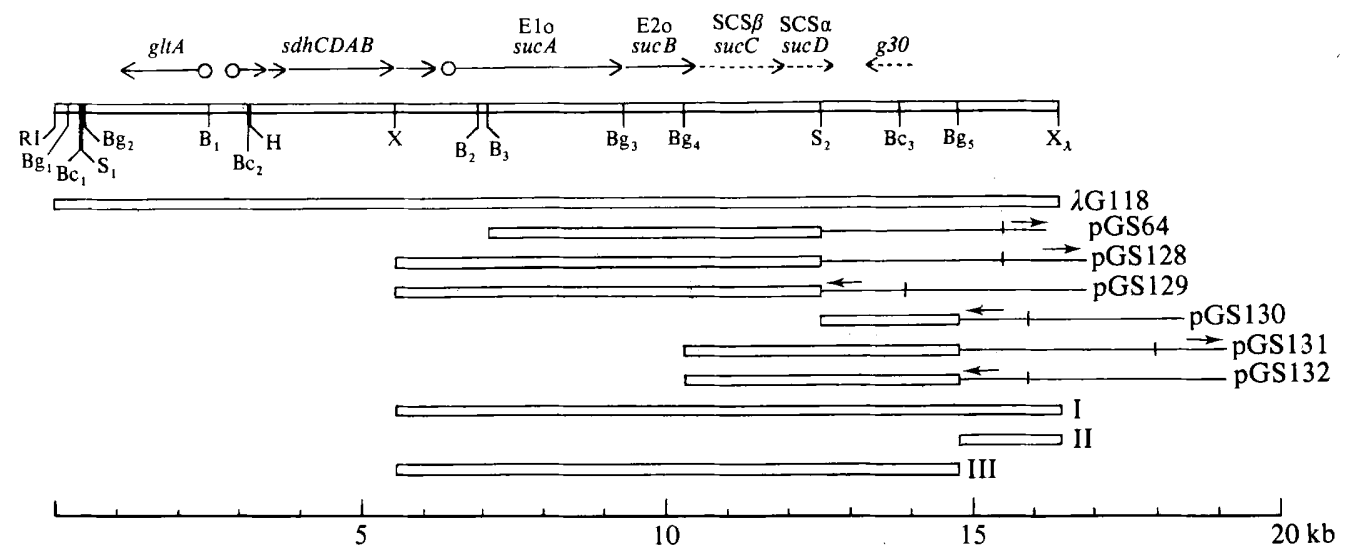

Fig. 1. Genetic and restriction map of the 16.4 to $16.9 \mathrm{~min}$ region of the $E$. coli linkage map containing the glt $A, s d h C D A B$ and $s u c A B$ genes, encoding citrate synthase, succinate dehydrogenase and the Elo and E2o components of the 2-oxoglutarate dehydrogenase complex respectively. The approximate locations and polarities of the genes encoding $\beta$ and $\alpha$ subunits of succinyl-CoA synthetase (sucC and sucD), and the unidentified $30 \mathrm{kDa}$ polypeptide $(\mathrm{g} 30)$, are shown. Left to right corresponds to clockwise on the $E$. coli linkage map. The restriction map shows targets for $B a m \mathrm{HI}(\mathrm{B}), B c I I(\mathrm{Bc}), B g l \mathrm{II}(\mathrm{Bg})$, EcoRI (RI), HindIII (H), SalI (S) and XhoI (X); $\mathrm{X}_{\lambda}$ denotes a $\lambda X h o I$ site (coordinate 33498) at the extreme end of a segment of $\lambda$ DNA $(<260 \mathrm{bp})$ that is fused to the bacterial DNA. Segments of DNA cloned into pBR322 are shown as open boxes; the vector is denoted by a thin line, the relative orientation being given by the Pst I site in the vector (vertical bar) and the polarity of the tet promoter (arrow). Also shown are three segments of DNA (I, II and III) which resisted subcloning.

\section{Studies with maxicells}

The maxicell technique was used to study the polypeptides expressed from plasmids pGS128, $129,130,131$ and 132, and a typical autoradiogram is shown in Fig. 2. The $\mathrm{Bg}_{4}-\mathrm{Bg}_{5}$ fragment of plasmids pGS131 and pGS132 encodes three unique bacterial polypeptides of 30,31 and $41 \mathrm{kDa}$, accounting for some $2.8 \mathrm{~kb}$ of the $4.1 \mathrm{~kb}$ of unassigned coding capacity in the cloned fragment. Because the $41 \mathrm{kDa}$ polypeptide is also expressed by pGS128, pGS129 and pGS64 (not shown), and because pGS130 expresses the $30 \mathrm{kDa}$ polypeptide, the relative order of the genes downstream of $s u c B$ must correspond to products of 41,31 and $30 \mathrm{kDa}$. Thus the two genes immediately downstream of $s u c B$ encode polypeptides of similar size to those reported for the $\beta$ and $\alpha$ subunits of SCS. It is interesting that analogous 42 and $32 \mathrm{kDa}$ polypeptides (expressed with the same polarity as the $s d h$ and $s u c$ gene products) were observed in post-infection labelling studies using $\lambda \mathrm{G} 136$, a $\lambda g l t A-s u c$ transducing phage having the bacterial DNA in the opposite orientation to $\lambda \mathrm{G} 118$ (Spencer \& Guest, 1982). These were previously thought to be fusion polypeptides because they were not detected with $\lambda$ G118. Additional polypeptides expressed by pGS128 and pGS129 correspond to the E1o (101 kDa, sucA) and E2o (55 kDa, sucB) components of the 2-oxoglutarate dehydrogenase (ODH) complex (Fig. 2). The existence of a third polypeptide $(50.5 \mathrm{kDa})$ is puzzling because there is insufficient coding capacity in the cloned DNA: it must be expressed from an overlapping gene, or represent a processed or degraded form of one of the other gene products. It is interesting that two or more bands corresponding to the E2p component of the pyruvate dehydrogenase complex were detected in post-infection labelling studies with hace-lpd transducing phages (Guest et al., 1981).

There are marked differences in the expression of some of the polypeptides depending on the orientation of the cloned fragment, the presence of the natural promoter and the influence of the tet promoter in the vector. Where expression is affected by orientation, it is predicted that a higher level of expression should be obtained when the gene is transcribed entirely or in part from the flanking tet promoter. Thus it would appear that the 41 and $31 \mathrm{kDa}$ polypeptides are expressed from the tet promoter in pGS131 (Fig. 1 and 2). This means that they are expressed with the same polarity as the suc $A B$ genes (clockwise on the $E$. coli chromosome) and, consistent 


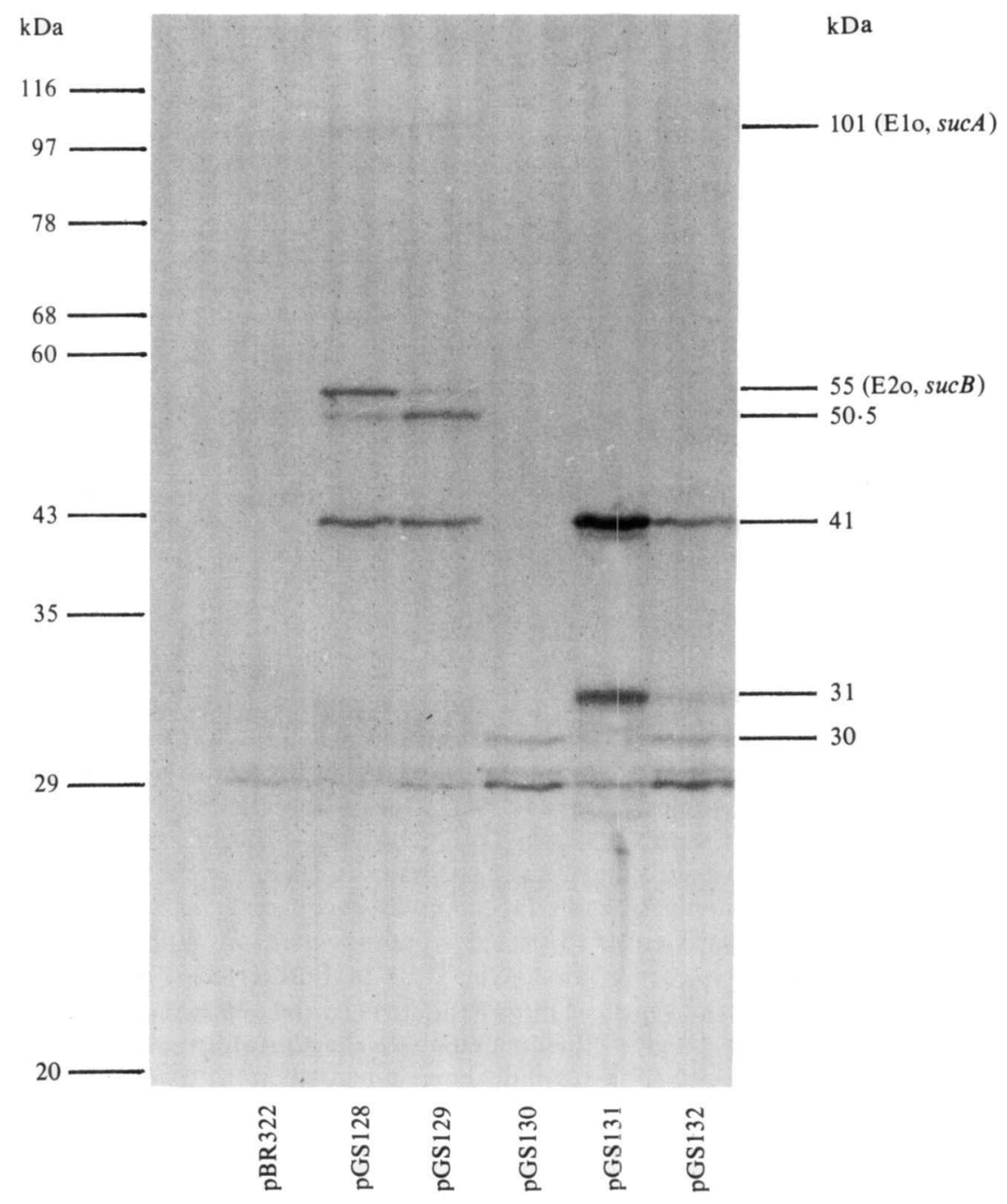

Fig. 2. Autoradiogram of ${ }^{14} \mathrm{C}$-labelled polypeptides expressed from the cloned genes. Plasmidcontaining strains were labelled for $2 \mathrm{~h}$ by the maxicell procedure. The molecular masses of the polypeptides are shown in $\mathrm{kDa}$, with the positions and molecular masses of the protein standards shown on the left hand side.

with previous transcription data, are likely to be distal genes in the suc operon (Spencer \& Guest, 1985 ). By the same reasoning the $30 \mathrm{kDa}$ polypeptide is expressed from the tet promoter in pGS132 (and pGS130) and the corresponding gene ( $g 30)$ has an anticlockwise polarity (Fig. 1). The expression of the 101 and $41 \mathrm{kDa}$ polypeptides from pGS128 and pGS129 appears to be unaffected by the orientation of cloning, consistent with these plasmids containing the natural suc promoter. However, the 55 and $50.5 \mathrm{kDa}$ polypeptides exhibit inversely related orientation effects, but they could still represent differently processed or degraded forms of the same polypeptide.

\section{Studies with $k d p$ deletion strains}

A series of strains with deletions extending from the $k d p$ gene has been isolated following temperature-induction of a $\lambda k d p$ prophage integrated in the $k d p$ region (Rhoads et al., 1978). Some of these require glutamate for aerobic growth on glucose minimal medium $\left(\mathrm{Glt}^{-}\right)$, 
Table 2. Activities of SCS, the $O D H$ complex and its constituent components in plasmidcontaining strains

Organisms were grown in L broth (PM191) or LG-0.1\%(TK3D18), harvested in late exponential phase and ultrasonic extracts prepared and assayed as described in the Methods. The specific activities are expressed as $\mu \mathrm{mol}$ substrate transformed (mg protein $)^{-1} \mathrm{~h}^{-1}$; values are means of results, which agreed to within $\pm 15 \%$, for several different extracts.

Enzyme specific activities in E. coli host strains:

\begin{tabular}{|c|c|c|c|c|c|c|c|c|}
\hline \multirow[b]{2}{*}{ Plasmid } & \multicolumn{4}{|c|}{ PM191 } & \multicolumn{4}{|c|}{ TK3D18 } \\
\hline & SCS & $\begin{array}{c}\mathrm{ODH} \\
\text { complex }\end{array}$ & Elo & E3 & SCS & $\begin{array}{c}\text { ODH } \\
\text { complex }\end{array}$ & Elo & E3 \\
\hline None & $5 \cdot 6$ & $1 \cdot 1$ & 1.0 & 8.9 & $<0.1$ & $<0.01$ & $<0.02$ & 1.0 \\
\hline pBR322 & $4 \cdot 7$ & $1 \cdot 2$ & $1 \cdot 1$ & $9 \cdot 2$ & $<0.1$ & $<0.01$ & $<0.02$ & $1 \cdot 2$ \\
\hline pGS64 & $6 \cdot 6$ & 1.9 & 1.4 & 11.6 & $<0.1$ & $<0.01$ & $<0.02$ & $1 \cdot 4$ \\
\hline pGS 128 & $4 \cdot 8$ & 3.0 & 11.7 & 8.7 & $<0.1$ & 1.5 & $16 \cdot 4$ & 0.9 \\
\hline pGS129 & 4.7 & 1.8 & $2 \cdot 3$ & 12.0 & $<0.1$ & 0.3 & $1 \cdot 1$ & $1 \cdot 1$ \\
\hline pGS 130 & $6 \cdot 0$ & 0.9 & 0.8 & 8.2 & $<0.1$ & $<0.01$ & $<0.02$ & 1.5 \\
\hline pGS131 & $21 \cdot 2$ & $1 \cdot 1$ & 1.2 & 7.9 & $23 \cdot 5$ & $<0.01$ & $<0.02$ & $1 \cdot 3$ \\
\hline pGS132 & $5 \cdot 4$ & 1.0 & 0.9 & 7.9 & 2.0 & $<0.01$ & $<0.02$ & 1.7 \\
\hline
\end{tabular}

indicative of deletions extending into or past the gltA gene, whereas others have a $\mathrm{Glt}^{+}$ phenotype. Enzymological tests with representative strains, TK3D01, 12, 14 and $18\left(\mathrm{Glt}^{-}\right)$and TK3D27 $\left(\mathrm{Glt}^{+}\right)$, showed that the Glt ${ }^{-}$strains not only lack citrate synthase but also succinate dehydrogenase, the ODH complex, Elo and SCS, suggesting that their deletions extend clockwise from $k d p$, through the $g l t A$ and $s d h C D A B$ genes into or beyond the suc operon. The $\mathrm{Glt}^{-}$deletion strains grow very poorly and glucose is essential even in rich media such as $\mathrm{L}$ broth. It is also interesting that despite the lack of ODH complex, succinate is not required for aerobic growth on glucose. This is consistent with previous findings that $s d h$ mutations suppress the Suc- phenotype of suc mutants (Creaghan \& Guest, 1978). Furthermore, it appears that the nutritional debility of these strains may be imposed in part by the absence of a gene(s) located outside the fragment cloned in $\lambda \mathrm{G} 118$. When plated on the deletion strains, this phage failed to generate lysogen-filled transduction plaques of the type found with $s d h$ and $s u c$ mutants (Spencer \& Guest, 1982).

\section{Enzymological studies with plasmid-containing strains}

The specific activities of SCS and the ODH complex and its constituent components were determined in ultrasonic extracts of plasmid-containing strains. Two hosts were used: PM191, which serves as a wild-type for the relevant genes; and the deletion strain TK3D18, which lacks the ODH complex and SCS activities. Representative results are shown in Table 2, and they confirm that the 31 and $41 \mathrm{kDa}$ polypeptides, seen in maxicells, are the $\alpha$ and $\beta$ subunits of SCS. Plasmid pGS131 produces a fourfold amplification of SCS in the wild-type strain whereas the other plasmids have no effect. Plasmid pGS131 also generates a similar activity in the deletion strain, and pGS132 produces a low but appreciable activity against the negligible background levels in this strain. These results are consistent with the transcript analysis, which indicates that the gene(s) downstream of sucB form part of the suc operon and have no independent promoter. The genes specifying the $\beta$ and $\alpha$ subunits of SCS have thus been designated sucC and sucD respectively. In pGS131 they are presumed to be transcribed from the tet promoter and in the multicopy situation the net result is a fourfold amplification of SCS activity. The low level of activity produced with pGS132 may be due to the weak vector promoter acting in the reverse direction (Queen \& Rosenberg, 1981).

Plasmids pGS 128 and pGS129 contain the $s u c A$ and $B$ genes with their own promoter and, as expected, PM191(pGS128) is amplified for both Elo (tenfold) and the ODH complex (twofold). In contrast PM191(pGS129) shows little, if any, amplification of either Elo or complex activity, although it is apparent that pGS129 is directing a low level of synthesis in the deletion strain 


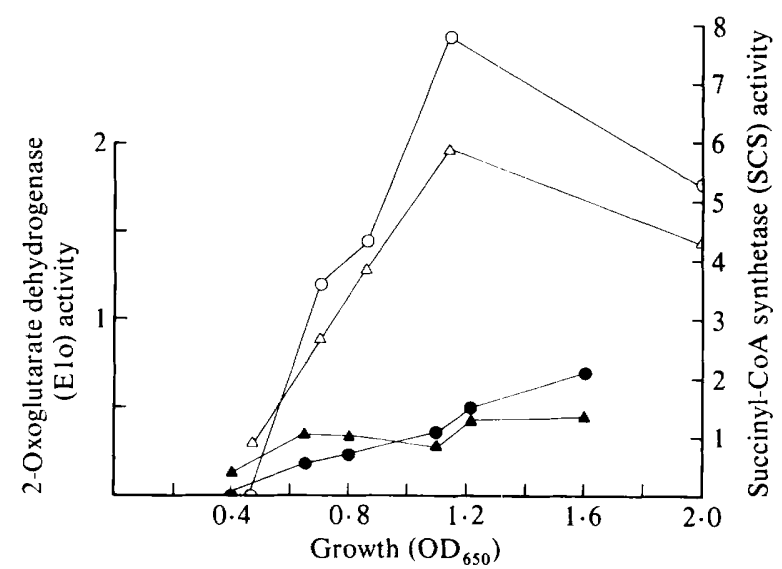

Fig. 3. Effect of glucose on the synthesis of SCS and Elo throughout the growth cycle of PM191(pBR322). Bacteria were grown on $L(O, \triangle)$ and LG $-1 \%(O, \Delta)$ broths and samples were taken at various times for measuring growth $\left(\mathrm{OD}_{650}\right)$ and the specific activities $\left.[\mu \mathrm{mol} \text { (mg protein })^{-1} h^{-1}\right]$ of $\operatorname{SCS}(O, O)$ and Elo $(\triangle, \Delta)$.

(Table 2). Thus it appears that the tet promoter is considerably enhancing the activity of the suc promoter in pGS128. This contrasts with the maxicell results where pGS128 and pGS129 appeared to express E1o equally. The activity of the E3 component remains relatively consfant in all the strains and the presence of excess Elo does not seem to induce or derepress expression of the chromosomal $l p d$ gene. This may account for the smaller amplification of ODH complex activity compared with E1o activity in PM191(pGS128). The E2o assay is particularly difficult with crude extracts and no significant amplifications were detected.

\section{Effect of different growth conditions on the expression of the suc genes}

The citric acid cycle enzymes are repressed during anaerobic growth and by glucose, and this repression is particularly marked for the $\mathrm{ODH}$ complex and succinate dehydrogenase, whereas other enzymes are maintained at a reduced level for biosynthetic or reductive purposes (Amarasingham \& Davis, 1965; Gray et al., 1966; Spencer \& Guest, 1973; Langley \& Guest, 1978). Succinyl-CoA synthetase is reported to be eight- to tenfold repressed by growth on glucose compared to succinate (Gibson et al., 1967). There has been no detailed analysis of SCS repression or derepression, but it is anticipated that low activities will be required during anaerobic or catabolite repression to provide succinyl-CoA for biosynthetic purposes. The citric acid cycle enzymes are also induced by growth on oxidizable substrates such as acetate or 2oxoglutarate (Gray et al., 1966; Langley \& Guest, 1978; Smith \& Neidhardt, 1983).

The Elo and SCS activities of PM191(pBR322) grown on L broth with and without $1 \%$ glucose show a marked and coordinate glucose repression throughout the exponential and stationary phases (Fig. 3). The peak of enzyme synthesis occurs in the late exponential phase, and cultures were harvested at this point in subsequent experiments involving growth under different conditions (Table 3). Unamplified strains show four- to sixfold reductions in Elo activity and fourfold reductions in SCS when grown on LG-1\% compared with L broth. Both enzymes are also strongly repressed in unamplified strains after anaerobic growth on LG-1\% but, whereas Elo is undetectable ( 40 to $>100$-fold repression), some SCS activity remains (fourto tenfold repression). In the plasmid-containing strains, the catabolite and anaerobic repressions of the plasmid-specified Elo (pGS128) and SCS (pGS131) activities are greatly reduced. Since the plasmid copy numbers based on $\beta$-lactamase activities are relatively constant, the lack of regulation is presumably because neither enzyme is being expressed from its own promoter.

The SCS and Elo activities were also measured after growth on minimal media with glucose, 2-oxoglutarate or acetate as substrates (Table 3). Once more a close coordinacy in the 

Table 3. Activities of SCS and Elo in plasmid-containing E. coli PM191 grown in different
media

Organisms were harvested at late exponential phase, and enzyme specific activities, expressed as $\mu \mathrm{mol}$ substrate transformed (mg protein $)^{-1} \mathrm{~h}^{-1}$, were measured in ultrasonic extracts as described in the Methods. Values are means of two or three determinations, which agreed to within $\pm 15 \%$.

Enzyme specific activities with plasmids:

Growth medium

L broth

LG-1\%

LG- $1 \%$ anaerobic

Glucose minimal

2-Oxoglutarate minimal

Acetate minimal

$\overbrace{\text { SCS }}^{\text {pGS128 }} \begin{array}{rr}\text { E10 } \\ 4 \cdot 3 & 11 \cdot 1 \\ 1 \cdot 1 & 7 \cdot 7 \\ 0.9 & 6 \cdot 3 \\ 3 \cdot 1 & 8 \cdot 6 \\ 6 \cdot 7 & 30 \cdot 0 \\ 9 \cdot 2 & 28.6\end{array}$

\begin{tabular}{|c|c|}
\hline \multicolumn{2}{|c|}{ pGS131 } \\
\hline SCS & E1o \\
\hline $14 \cdot 3$ & 0.9 \\
\hline $7 \cdot 5$ & 0.2 \\
\hline 3.8 & $<0.02$ \\
\hline 39.0 & 0.5 \\
\hline $238 \cdot 6$ & 1.6 \\
\hline $133 \cdot 2$ & $1 \cdot 3$ \\
\hline
\end{tabular}

\begin{tabular}{|c|c|}
\hline \multicolumn{2}{|c|}{ pGS132 } \\
\hline SCS & E1o \\
\hline $4 \cdot 4$ & 0.8 \\
\hline $1 \cdot 1$ & $0 \cdot 2$ \\
\hline $1 \cdot 1$ & $<0.02$ \\
\hline 6.8 & 0.3 \\
\hline 8.9 & 0.5 \\
\hline $16 \cdot 7$ & 0.8 \\
\hline
\end{tabular}

chromosome-derived expression of Elo and SCS is observed, consistent with their being expressed from the same promoter. Both enzymes are induced approximately twofold on 2oxoglutarate, and three- to fivefold on acetate, relative to glucose. The plasmid-expressed enzymes, Elo from pGS128 and SCS from pGS131, also increase. However, $\beta$-lactamase assays indicate that the plasmid copy numbers are raised some 1.5 to 3.0 -fold on acetate and 2oxoglutarate compared with all the other growth conditions.

\section{DISCUSSION}

The subcloning of DNA in the suc $(16.8 \mathrm{~min})$ region of the $E$. coli chromosome has revealed three new genes downstream of $s u c B$. Two of the genes, encoding polypeptides of 41 and $31 \mathrm{kDa}$, have been identified, on the basis of size and enzyme activities, as the $\beta$ and $\alpha$ subunits of succinyl-CoA synthetase. They have the same polarity as the $s u c A$ and $s u c B$ genes, and because a transcript analysis has shown that the gene(s) downstream of $s u c B$ are part of the $s u c$ operon (Spencer \& Guest, 1985), they have been designated $\operatorname{suc} C(\beta)$ and $\operatorname{suc} D(\alpha)$. The other gene $(g 30)$ is polarized in the opposite orientation to the suc operon and encodes an unidentified polypeptide of $30 \mathrm{kDa}$. The chromosome-specified SCS and Elo activities appear to be coordinately regulated, which is consistent with their expression from the same promoter. A possible exception occurs under anaerobic conditions where E1o is more severely repressed than SCS. There is no evidence for an independent $s u C C D$ promoter or transcript, but in pGS132, where the sucCD genes are cloned without the suc promoter in an orientation counter to the tet promoter, a low level of expression is observed in maxicells and enzymologically. This expression could stem from a weak and hitherto undetected sucCD promoter, which could also account for the low anaerobic expression of SCS and may be physiologically significant. Alternatively, it could derive from a weak pBR322 promoter that can transcribe anticlockwise through the tet region (Queen \& Rosenberg, 1981). It is presumed that the high SCS expression seen with pGS131 is due to transcription from the tet promoter, and it is therefore not surprising that the SCS activity is not subject to glucose or anaerobic repression.

The situation with plasmids pGS128 and pGS129 is rather different because these plasmids contain the sucA, $B$ and $C$ genes together with the suc promoter. Nevertheless the enzymological results show that in pGS128 the tet promoter influences suc expression, probably by enhancing the effect of the suc promoter. For this to occur, transcription from the tet promoter would have to proceed through the IS-like palindromic units or REP (repeated extragenic palindromic) sequences found between $s d h B$ and $s u c A$ (Darlison et al., 1984). No readthrough transcription was detected here by transcript mapping, even though a strain harbouring pGS128 was used as a potentially amplified source of RNA, but there are nonetheless good reasons to suspect that it may occur (Spencer \& Guest, 1985). Indeed, the great majority of REP sequences appear to be 
transcribed (Stern et al., 1984), and it is therefore possible that, at least under some circumstances, the $s u c$ genes are expressed from the upstream $s d h$ promoter. If the high expression of the sucA gene in pGS128 is directed by the tet promoter no glucose and anaerobic repression would be expected.

The enzymes of the citric acid cycle are induced by oxidizable substrates such as acetate, and the ODH complex is induced by its substrate, 2-oxoglutarate (Gray et al., 1966; Langley \& Guest, 1978). Little is known about the mechanism of this induction. In this study, coordinatelyenhanced levels of expression of both Elo and SCS were observed in wild-type strains grown on acetate and, to a lesser extent, 2-oxoglutarate. In the plasmid-containing strains the results have to be considered against the increased copy numbers in acetate- and 2-oxoglutarate-grown organisms. There is nevertheless a disproportionately high induction of SCS activity with pGS131 even though the sucC and $D$ genes are expressed from the tet promoter. It is conceivable that the REP sequences between the tet promoter and the sucCD genes may be involved in regulating the expression of the downstream genes.

The remarkable clustering of citric acid cycle genes having the same polarity, viz. $\operatorname{sdh} C D A B$ and sucABCD, raises questions concerning its regulatory significance, and the poorlyunderstood regulation of the citric acid cycle as a whole. This regulation is now being studied by fusing promoters to the galactokinase gene $(\mathrm{galK})$, in order to locate control regions and explore physiological effects in the presence and absence of potentially repressive gene products. The present paper describes the first cloning of the genes encoding succinyl-CoA synthetase from any organism; it paves the way for elucidating the nucleotide sequence (Buck et al., 1985) and will greatly facilitate future work on the structure and mechanism of the enzyme.

This work was supported by the Science and Engineering Research Council.

\section{REFERENCES}

Amarasingham, C. R. \& Davis, B. D. (1965). Regulation of $\alpha$-ketoglutarate dehydrogenase formation in Escherichi coli. Journal of Biological Chemistry 240, 3664-3668.

BaCHMANN, B. J. (1983). Linkage map of Escherichia coli $\mathrm{K} 12$, edition 7. Microbiological Reviews 47, 180230.

BRIDGER, W. A. (1974). Succinyl-CoA synthetase. In The Enzymes, 3rd edn, vol. 10, pp. 581-606. Edited by P. D. Boyer. New York: Academic Press.

Bridger, W. A., Ramaley, R. F. \& Boyer, P. D. (1969). Succinylcoenzyme A synthetase from Escherichia coli. Methods in Enzymology 13, 70-75.

Bucx, D., Spencer, M. E. \& Guest, J. R. (1985). Primary structure of the succinyl-CoA synthetase of Escherichia coli. Biochemistry 24, 6245-6252.

Creaghan, I. T. \& Guest, J. R. (1972). Amber mutants of the $\alpha$-ketoglutarate dehydrogenase gene of Escherichia coli K12. Journal of General Microbiology 71, 207-220.

Creaghan, I. T. \& Guest, J. R. (1978). Succinate dehydrogenase-dependent nutritional requirement of the succinate dehydrogenase of Escherichia coli. Journal of General Microbiology 107, 1-13.

Darlison, M. G. \& Guest, J. R. (1984). Nucleotide sequence encoding the iron-sulphur protein subunit of the succinate dehydrogenase of Escherichia coli. Biochemical Journal 223, 507-517.

Darlison, M. G., Spencer, M. E. \& Guest, J. R. (1984). Nucleotide sequence of the sucA gene encoding the 2-oxoglutarate dehydrogenase of $E s$ cherichia coli K12. European Journal of Biochemistry 141, 351-359.

Dretzen, G., Bellard, M., Sassone-Corsi, P. \&
Chambon, P. (1981). A reliable method for the recovery of DNA fragments from agarose and acrylamide gels. Analytical Biochemistry 112, 295298.

FroEHLICH, B. \& EPSTEIN, W. (1981). Escherichia coli mutants in which transcription is dependent on rec $A$ function. Journal of Bacteriology 147, 1117-1120.

Gibson, J., UpPer, C. D. \& Gunsalus, I. C. (1967). Succinyl Coenzyme A synthetase from Escherichia coli. Journal of Biological Chemistry 242, 2474-2477.

Gray, C. T., Wimpenny, J. W. T. \& Mossman, M. R. (1966). Effects of aerobiosis, anaerobiosis and nutrition on the formation of Krebs cycle enzymes in Escherichia coli. Biochimica et biophysica acta 117, 33-41

GUEST, J. R. (1981). Hybrid plasmids containing the citrate synthetase gene ( $g$ lt $A$ ) of Escherichia coli K 12 . Journal of General Microbiology 124, 17-23.

Guest, J. R., Cole, S. T. \& Jeyaseelan, K. (1981). Organization and expression of the pyruvate dehydrogenase complex genes of Escherichia coli K12. Journal of General Microbiology 127, 65-79.

Higgins, C. J., Ames, G. F.-L., Barnes, W. M., Clement, J. N. \& Hofnung, M. (1982). A novel intercistronic regulatory element of prokaryotic operons. Nature, London 298, 760-762.

KNIGHT, E. \& Gunsalus, I. C. (1962). Formation and breakdown of acyl lipoic acids. Methods in Enzymo$\log y 5,651-656$.

LANGley, D. \& Guest, J. R. (1977). Biochemical genetics of the $\alpha$-keto acid dehydrogenase complexes of Escherichia coli $\mathrm{K} 12$ : isolation and biochemical properties of deletion mutants. Journal of General Microbiology 99, 263-276. 
Langley, D. \& Guest, J, R. (1978). Biochemical genetics of the $\alpha$-keto acid dehydrogenase complexes of Escherichia coli K12: genetic characterization and regulatory properties of deletion mutants. Journal of General Microbiology 106, 103-117.

Ner, S. S., Bhayana, V., Bell, A. W., Giles, I. G., Duckworth, H. W. \& Bloxham, D. P. (1983). Complete sequence of the gltA gene encoding citrate synthase in Escherichia coli. Biochemistry 22, 52435249.

Queen, C. \& Rosenberg, M. (1981). A promoter of pBR322 activated by cAMP receptor protein. Nucleic Acid Research 9, 3365-3377.

Rhoads, D. B., Laimins, L. \& Epstein, W. (1978). Functional organization of the $k d p$ genes of Escherichia coli K-12. Journal of Bacteriology 135, 445-452.

Ross, G. W. \& O'Callaghan, C. H. (1975). $\beta$ Lactamase assays. Methods in Enzymology 43, 69-85.

SANCAR, A., HaCk, A. M. \& RupP, W. D. (1979). Simple method for identification of plasmid-coded proteins. Journal of Bacteriology 137, 692-693.

SMITH, M. W. \& NeIDHARDT, F. C. (1983). 2-Oxoacid dehydrogenase complexes of Escherichia coli : cellular amounts and patterns of synthesis. Journal of Bacteriology 156, 81-88.

SPENCER, M. E. \& Guest, J. R. (1973). Isolation and properties of fumarate reductase mutants of Escherichia coli. Journal of Bacteriology 114, 563-570.

SPENCER, M. E. \& Guest, J. R. (1982). Molecular cloning of four tricarboxylic acid cycle genes of Escherichia coli. Journal of Bacteriology 151, 542-552.

SPENCER, M. E. \& Guest, J. R. (1985). Transcription analysis of the $\operatorname{suc} A B$, aceEF and lpd genes of Escherichia coli. Molecular and General Genetics 200, 145-154.
Spencer, M. E., Darlison, M. G., Stephens, P. E., DuCKenfield, I. K. \& Guest, J. R. (1984). Nucleotide sequence of the $\operatorname{sucB}$ gene encoding the dihydrolipoamide succinyltransferase of Escherichia coli $\mathrm{K} 12$ and homology with the corresponding acetyltransferase. European Journal of Biochemistry 141, 361-374.

Stephens, P. E., Darlison, M. G., Lewis, H. M. \& GuEST, J. R. (1983). The pyruvate dehydrogenase complex of Escherichia coli K12. Nucleotide sequence encoding the pyruvate dehydrogenase component. European Journal of Biochemistry 133, 155162.

Stern, M. J., Ames, G. F.-L., Smith, N. H., Robinson, C. E. \& Higgins, C. F. (1984). Repetitive extragenic palindromic sequences: a major component of the bacterial genome. Cell 37, 1019-1026.

VoGel, H. \& BONNER, D. M. (1956). A convenient growth medium for Escherichia coli and some other microorganisms. Microbial Genetics Bulletin 13, 4344.

VOGEL, H. J. \& BRIDGER, W. A. (1982). A phosphorus 31 nuclear magnetic resonance study of the intermediates of the Escherichia coli succinyl-coenzymeA synthetase reactions. Journal of Biological Chemistry 257, 4834-4842.

WeITZMAN, P. D. J. (1981). Unity and diversity in some bacterial citric acid cycle enzymes. Advances in Microbial Physiology 22, 185-244.

WoOd, D., Darlison, M. G., Wilde, R. J. \& Guest, J. R. (1984). Nucleotide sequence encoding the flavoprotein and hydrophobic subunits of the succinate dehydrogenase of Escherichia coli. Biochemical Journal 222, 519-534. 